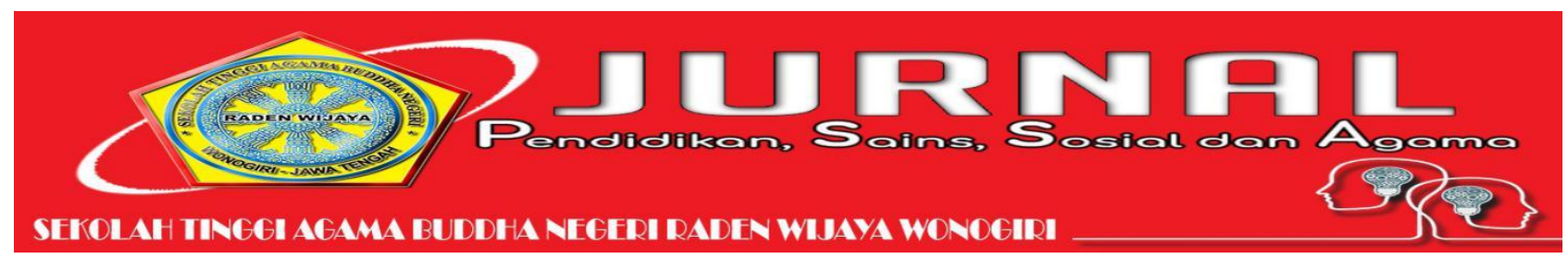

\title{
IMPLEMENTASI SIAKAD TERHADAP AKUNTABILITAS AKADEMIK DI STAI DR. KH. EZ. MUTTAQIEN PURWAKARTA
}

\author{
Asep Lukman Hamid ${ }^{1}$, Dyah Wulandari ${ }^{2}$ \\ STAI DR. KH. EZ. Muttaqien Purwakarta \\ aseplukman@staimuttaqien.ac.id,dyahwulandari970@gmail.com
}

\begin{abstract}
Abstrak
Pemanfaatan Teknologi Informasi tidak hanya pada organisasi sektor bisnis, tetapi juga pada sektor publik. Salah satu instansi sektor publik yang memanfaatkan TI adalah Perguruan Tinggi. Bagi Perguruan Tinggi TI telah menjadi kebutuhan dasar (basic need) untuk menunjang proses pendidikan, teristimewa dimasa pandemi. TI sangat dibutuhkan dalam meningkatkan efisiensi, kualitas dan produktivitas bagi manajemen pendidikan. Penelitian ini dilakukan pada STAI DR. KH. EZ. Muttaqien Purwakarta dengan pertimbangan untuk mengetahui keberhasilan sistem informasi akademik (SIAKAD) apakah membawa dampak positif dalam peningkatan akuntabilitas kegiatan akademik ataukah sebaliknya. Tujuan dari penelitian ini adalah: (1) untuk mengetahui implementasi Sistem Informasi Akademik (SIAKAD) di STAI DR. KH. EZ. Muttaqien Purwakarta; (2) untuk mengetahui sistem akuntabilitas akademik di STAI DR. KH. EZ. Muttaqien Purwakarta, dan (3) untuk mengetahui implementasi Sistem Informasi Akademik terhadap akuntabilitas akademik di STAI DR. KH. EZ. Muttaqien Purwakarta. Metode yang dipergunakan dalam penelitian ini adalah kualitatif dengan pendekatan konten analisis. Dengan metode kualitatif, maka data yang didapat lebih lengkap, mendalam, kredibel, dan bermakna sehingga tujuan penelitian dapat dicapai. Untuk melihat bagaimana gambaran atau implementasi SIAKAD peneliti akan merumuskan 10 indikator yang dinyatakan dalam survei persepsi. Jawaban persetujuan merupakan persepsi partisipan berdasarkan pada apa yang terjadi/senyatanya. Survei ini adalah survei persepsi face to face interview dengan metode stratified random sampling. Hasil penelitian menunjukkan bahwa implementasi SIAKAD disetujui telah terwujud di kampus STAI DR. KH. EZ. Muttaqien Purwakarta dengan jumlah angka rata-rata 64\% menyatakan baik dan sangat baik. Demikian juga dengan akuntabilitas akademik di kampus STAI DR. KH. EZ. Muttaqien Purwakarta dipersepsikan telah terwujud dengan dengan jumlah angka rata-rata 57\% baik dan sangat baik. Hal ini menunjukkan bahwa implementasi sistem informasi manajemen akademik berdampak terhadap akuntabilitas akademik STAI DR. KH. EZ. Muttaqien Purwakarta.
\end{abstract}

Kata kunci: Sistem Informasi, Akademik, Akuntabilitas

\begin{abstract}
Utilization of information technology is not only in business sector organizations, but also in the public sector. One of the public sector agencies that utilize IT is a university. For Higher Education IT has become a basic need to support the educational process, especially during the pandemic. IT is needed to improve the efficiency, quality and productivity of education management. The research was conducted at STAI DR. KH. EZ. Muttaqien Purwakarta with the consideration to determine the success of the academic information system (SIAKAD) whether it has a positive impact in increasing the accountability of academic activities or vice versa. The aims of this study are: (1) to determine the implementation of SIAKAD; (2) to determine the academic accountability system, and (3) to determine the implementation of SIAKAD on academic accountability. The method used in this research is qualitative with content analysis approach. With qualitative methods, the data obtained is more complete, in-depth, credible, and meaningful so that the research objectives can be achieved. To see how SIAKAD is described, the researcher will formulate 10 indicators stated in the perception survey. The approval answer is the participant's perception based on what happened. This survey is a face to face interview perception survey with stratified random sampling method. Furthermore, the data can also be obtained by the method of observation and documentation. The results showed that the approved SIAKAD implementation had been realized on the STAI DR. KH. EZ. Muttaqien Purwakarta with an average score of $64 \%$ said it was good and very good. Likewise with academic accountability at the STAI DR. KH. EZ. Muttaqien Purwakarta is perceived to have been realized with an average score of $57 \%$ good and very good. This shows that the implementation of SIAKAD has an impact on academic accountability at STAI DR. KH. EZ. Muttaqien Purwakarta.
\end{abstract}

Keywords: Information System, Academic, Accountability. 


\section{PENDAHULUAN}

Perkembangan Teknologi Informasi
pada dekade terakhir ini sangat pesat. Pemanfaatannya dalam kehidupan masyarakat juga mengalami peningkatan yang sangat signifikan. Pengolahan informasi melalui kegiatan membaca membutuhkan kreativitas dikarenakan dalam membaca terdapat aktivitas untuk memprediksi informasi yang tidak diketahui (Widodo, 2021). Berbagai kepentingan menjadi dasar pertimbangan penggunaannya, dari mulai hanya sebagai life-style, prestise sampai dengan menjadi perangkat dan sarana yang menempati posisi yang vital dalam kehidupan. Pemanfaatan ini dikarenakan teknologi dapat memberikan informasi secara cepat, tepat dan akurat sehingga akan berdampak pada meningkatnya produktifitas baik dari segi kualitas maupun kuantitasnya. (Wawan: 2002) Bahkan di era industri 4.0 ini eksistensi teknologi informasi telah menjadi primadona dalam memenuhi hajat hidup manusia.

Penggunaan teknologi informasi (selanjutnya disebut $\mathrm{TI}$ ) terjadi bukan hanya pada masing-masing individu melainkan meluas pada berbagai sektor kehidupan manusia, mulai dari sektor bisnis/ekonomi, pemerintahan, pariwisata, manufaktur, transfortasi, kesehatan dan pendidikan. Dari sektor-sektor tersebut pendidikan -sebagai sektor publik - merupakan salah satu sektor yang paling dominan dalam pemanfaatan TI. Aplikasi TI di sektor pendidikan dianggap dominan karena memiliki beberapa keunggulan diantaranya: 1. Informasi yang dibutuhkan akan semakin cepat dan mudah di akses untuk kepentingan Pendidikan; 2. Inovasi dalam pembelajaran semakin berkembang dengan adanya inovasi e-learning; dan 3. Kemajuan TI juga akan memungkinkan berkembangnya kelas virtual atau kelas yang berbasis teleconference yang tidak mengharuskan sang pendidik dan peserta didik berada dalam satu ruangan. Adapun platform yang sering digunakan dalam kelas virtual atau yang berbasis teleconference meliputi seperti platform Google Classroom, Zoom Meeting, Whatsapp, Google Meet, dan sebagainya.

Selain itu, yang paling penting penggunaan TI pada dunia pendidikan dibutuhkan untuk meningkatkan efisiensi, kualitas dan produktivitas bagi manajemen pendidikan itu sendiri. Penggunaan TI di Perguruan Tinggi ternyata membuat kinerja organisasi lebih efektif, efisien dan kompetitif. (Akadun: 2009) Terlebih disaat pandemi, penggunaan TI di sektor pendidikan terus meningkat sangat drastis. Penggunaan aplikasi pembelajaran secara online atau daring mengalami peningkatan. Hasil survey/riset yang dilakukan oleh Universitas Airlangga Surabaya menunjukkan bahwa pertumbuhan pemanfaatan TI di sektor pendidikan meningkat hingga 33\% selama Q1 2020 dibandingkan Q1 2019 (https://selular.id/: 2020)

Seiring adanya pencegahan penyebaran COVID 19 pemerintah menetapkan adanya protokol kesehatan dengan $3 \mathrm{M}$, yaitu: memakai masker, mencuci tangan serta menjaga jarak dan menjauhi kerumunan (social distancing/physical distancing). Melalui kebijakan ini tentu berdampak pada sektor pendidikan teristimewa bagi Perguruan Tinggi. Berkenaan dengan ini, pemerintah melalui Kementerian Pendidikan dan Kebudayaan, telah melarang perguruan tinggi untuk melaksanakan perkuliahan tatap muka (konvensional) dan memerintahkan untuk menyelenggarakan perkuliahan atau pembelajaran secara daring (Surat Edaran Kemendikbud Dikti No. 1 tahun 2020). Perguruan tinggi dituntun untuk dapat menyelenggarakan pembelajaran secara daring atau online. Hal senada juga dinyatakan oleh Kementerian Agama yang mengeluarkan Surat Edaran Nomor: 657/03/2020 tentang Upaya pencegahan penyebaran COVID 19 (Corona) di Perguruan Tinggi Agama Islam dengan tidak melakukan perkuliahan secara tatap muka.

Atas intruksi tersebut, hampir semua Perguruan Tinggi dengan cepat merespon intruksi pemerintah untuk tidak menyelenggarakan perkuliahan secara tatap muka tetapi diganti dengan daring atau online. Tidak terkecuali STAI DR. KH. EZ. Muttaqien Purwakarta dengan tanggap telah mengeluarkan surat edaran tentang perkuliahan atau pembelajaran secara daring dalam rangka pencegahan penyebaran corona virus diesease (Covid-19) di lingkungan STAI DR. KH. EZ. Muttaqien Purwakarta serta menerbitkan buku Panduan Pembelajaran Daring Kondisi Darurat Covid 19. Peralihan perkuliahan dari tatap muka ke online tentu memerlukan piranti pendukungnya, maka penggunaan TI merupakan suatu keniscayaan atau dengan perkataan lain bahwa TI adalah sebagai jawaban atas perubahan pembelajaran.

Selain TI sebagai jawaban atas perubahan perkuliahan di masa pandemi, TI juga berperan 
dalam menjaga kualitas pelayanan akademik bagi para stakeholder baik itu orang tua/wali mahasiswa, dunia usaha, mahasiswa, calon mahasiswa dan alumni. Dengan tersedianya TI, terutama dalam penyebaran informasi seputar kegiatan akademik kampus akan berimbas pada kepercayaan atau animo stakeholder terhadap perguruan tinggi semakin meningkat. Saat ini, banyak perguruan tinggi yang telah mengaplikasikan TI yang berkaitan dengan proses peningkatan mutu pelayanan akademik, salah satunya STAI DR. KH. EZ. Muttaqien Purwakarta. Sejak tahun 2011, STAI telah mengaplikasikan TI berupa Sistem Informasi Akademik (SIAKAD) dalam rangka menghasilkan informasi yang lebih bernilai guna, transparan dan akuntabel. Penggunaan aplikasi TI ini sangatlah urgent karena ia memiliki prinsip untuk melayani kebutuhan informasi secara tepat waktu (fast), tepat guna (accurate), dan tepat sasaran (relevant). (Sri: 2000)

Salah satu aplikasi TI yang kerap dipergunakan perguruan tinggi dalam menjaga mutu akademik adalah piranti Sistem Informasi Akademik (SIAKAD). SIAKAD merupakan sebuah perangkat untuk mendukung penyelenggaraan pendidikan disatuan pendidikan dan digunakan untuk menyampaikan program manajemen kualitas kepada seluruh civitas akademika dan stakeholder yang berbasis teknologi informasi dan komunikasi seperti internet dan local area network, sehingga satuan pendidikan dapat menyediakan layanan akademik yang lebih baik, efektif, dan efisien termasuk layanan akademik disebuah perguruan tinggi (Herson: 2016). SIAKAD juga merupakan sistem perencanaan bagian dari pengendalian internal suatu institusi pendidikan yang meliputi pemanfaatan manusia, dokumen, teknologi, dan prosedur standar untuk memecahkan masalah akademik seperti rencana studi, hasil studi, transkrip nilai, grafik nilai, kartu hak ujian, daftar hadir mahasiswa, dan keuangan.

Dalam work paper (kertas kerja) ini peneliti akan menguji ulang sebagian rantai teknologi-kinerja untuk memprediksi dampak kinerja individual yang ditimbulkan oleh teknologi sistem informasi dengan mengganti variabel task-technology-fit dengan variabel kemudahan penggunaan, karena menurut Goodhue dan Thompson, faktor tasktechnologi-fit memiliki kelemahan, yaitu hanya menekankan pada faktor kesesuaian teknologi dengan tugas, tanpa mengukur evaluasi pemakai terhadap kinerja. Peningkatan kinerja tidak hanya dipengaruhi oleh task-technologi fit, tetapi juga tergantung pada faktor-faktor lain (misal kebiasaan, faktor sosial dan lainnya) (Agung dan Dede: 2016).

Penelitian ini akan dilakukan STAI DR. KH. EZ. Muttaqien Purwakarta dengan beberapa pertimbangan. Pertama, bahwa teknologi informasi telah dimanfaatkan secara luas dan merata di STAI DR. KH. EZ. Muttaqien Purwakarta. Kedua, bahwa terjadi pengembangan sistem informasi pada STAI DR. KH. EZ. Muttaqien Purwakarta, sehingga perlu diketahui dampak sistem informasi terhadap produktivitas kinerja. Ketiga, penelitian tentang implementasi pemanfaatan sistem informasi akademik terhadap kinerja individual dengan variabel moderating kemudahan penggunaan belum banyak dilakukan di sektor publik. Keempat, adanya transisi dari sistem informasi berbasis manual kepada sistem informasi berbasis internet/web dianggap mampu menunjang kegiatan akademik mahasiswa aktif di STAI DR. KH. EZ. Muttaqien Purwakarta.

Berdasarkan alur pikir sebagaimana dipaparkan diatas, dalam rangka mengetahui keberhasilan sistem informasi akademik (SIAKAD) tersebut membawa dampak positif dalam peningkatan akuntabilitas kegiatan akademik maka dilakukan suatu penelitian dengan judul "Implementasi Sistem Informasi Akademik (SIAKAD) terhadap Akuntabilitas Akademik di STAI DR. KH. EZ. Muttaqien Purwakarta"

\section{METODE}

Metode yang dipergunakan dalam penelitian ini adalah kualitatif dengan pendekatan konten analisis. Dengan metode kualitatif, maka data yang didapat lebih lengkap, mendalam, kredibel, dan bermakna sehingga tujuan penelitian dapat dicapai. Untuk melihat bagaimana gambaran atau implementasi SIAKAD peneliti akan merumuskan 10 indikator yang dinyatakan dalam survei persepsi. Jawaban persetujuan merupakan persepsi partisipan berdasarkan pada apa yang terjadi/senyatanya. Survei ini adalah survei persepsi face to face interview dengan metode stratified random sampling. Selanjutnya juga data di dapat dengan metode observasi dan dokumentasi.

Penelitian ini menggunakan data primer dan sekunder. Contoh data primer adalah data yang diperoleh dari responden melalui kuisioner, kelompok fokus, dan panel, atau juga data hasil wawancara peneliti dengan nara sumber. Data sekunder adalah data yang diperoleh dari pihak lain atau hasil penelitian pihak lain atau data yang 
sudah tersedia sebelumnya yang diperoleh dari pihak lain yang berasal dari buku-buku, literatur, artikel dan jurnal ilmiah. Aktivitas dalam analisis data kualitatif dilakukan secara interaktif dan berlangsung secara terus menerus sampai tuntas, sehingga datanya sudah jenuh. Aktivitas dalam analisis data, yaitu data collection, data reduction, data display, dan conclusion drawing/verification. Selanjutnya Pengujian kredibilitas data atau kepercayaan terhadap data hasil penelitian kualitatif antara lain dilakukan dengan perpanjangan pengamatan, peningkatan ketekunan dalam penelitian, triangulasi, diskusi dengan teman sejawat, analisis kasus negatif, dan member check.

\section{HASIL}

\section{Implementasi Sistem Informasi}

Akademik di STAI DR. KH. EZ. Muttaqien Purwakarta

Untuk melihat bagaimana gambaran pelaksanaan SIAKAD, peneliti menyebar angket ke sejumlah mahasiswa. Berikut ini adalah data jumlah mahasiswa yang telah berkontribusi dalam memberikan keterangan/jawaban mengenai implementasi SIAKAD di STAI DR. KH. EZ. Muttaqien Purwakarta.

Tabel 1.

Data Jumlah Responden Mahasiswa

\begin{tabular}{|c|l|c|c|}
\hline No & \multicolumn{1}{|c|}{ Prodi } & Jumlah & Persentase \\
\hline 1 & PAI & 71 & $65,74 \%$ \\
\hline 2 & AS & 0 & 0 \\
\hline 3 & EKOS & 4 & $3,70 \%$ \\
\hline 4 & PBA & 10 & $9,25 \%$ \\
\hline 5 & KPI & 1 & $0.92 \%$ \\
\hline 6 & PIAUD & 22 & $20,37 \%$ \\
\hline & $\begin{array}{l}\text { Jumlah } \\
\text { Mahasiswa }\end{array}$ & 108 & $100 \%$ \\
\hline
\end{tabular}

Adapun pernyataan penelitian yang menggambarkan Implementasi Siakad adalah sebagai berikut:

a. Sistem pengambilan mata kuliah yang di sediakan oleh Sistem Informasi Akademik terorganisir;

b. Informasi yang diberikan oleh Sistem Informasi Akademik jelas dan cepat;

c. Pengoperasian Sistem Informasi Akademik mudah dan dapat mempermudah kegiatan kemahasiswaan dan perkuliahan;

d. Sistem Informasi Akademik mudah diakses dimanapun dan kapanpun;

e. Kerahasiaan data Sistem Informasi Akademik terjamin aman dan tidak mudah di hack;

f. Penyampaian informasi tepat waktu;

g. Informasi data disajikan sesuai kebutuhan dan sesuai dengan kegiatan;

h. Ketersediaan Informasi KRS dan KHS online sudah lengkap;

i. Mengalami Kemudahan dalam Pengambilan KRS dan KHS secara Online;

j. Proses informasi Nilai di SIAKAD mengalami kemudahan.

Berikut ini merupakan hasil survei persepsi yang diberikan kepada mahasiswa dengan berdasarkan pada kesepuluh pernyataan penelitian yang kemudian di jawab dengan skala linkert sangat baik, baik, cukup baik, kurang baik dan tidak baik.

\section{Gambar 1.}

Hasil Survey Persepsi Mahasiswa terhadap Implementasi Siakad

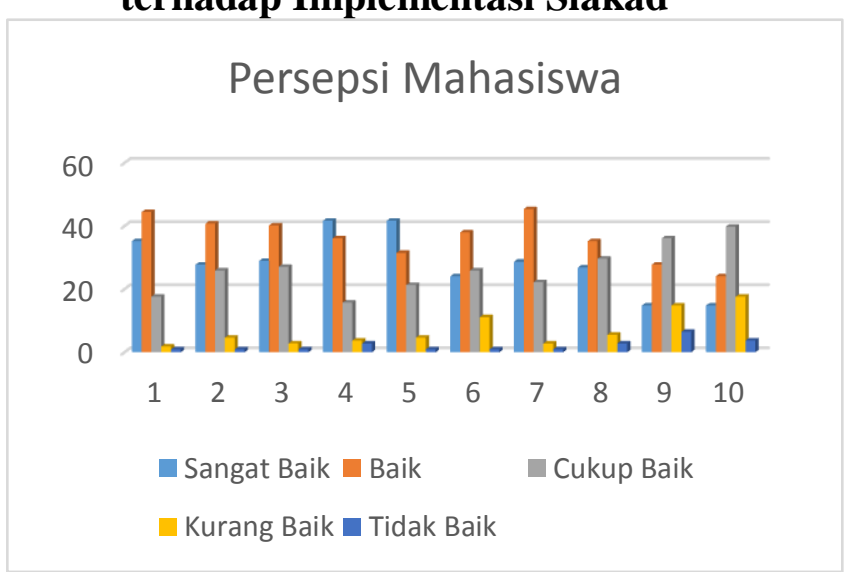

Adapun deskripsi dan hasil temuan lapangan menunjukkan data sebagai berikut:

a. Sistem pengambilan mata kuliah yang di sediakan oleh Sistem Informasi Akademik dinyatakan telah terorganisir di STAI DR. KH. EZ. Muttaqien Purwakarta dengan baik dengan persentase jawaban $44 \%$ dan persentase jawaban $35 \%$ menyatakan sangat baik. 
b. Informasi yang diberikan oleh Sistem Informasi Akademik jelas dan cepat dinyatakan telah terimplementasi di STAI DR. KH. EZ. Muttaqien Purwakarta dengan baik dengan persentase jawaban $41 \%, 28 \%$ menyatakan sangat baik dan $26 \%$ menyatakan cukup baik.

c. Pengoperasian Sistem Informasi Akademik yang mudah dan dapat mempermudah kegiatan kemahasiswaan dan perkuliahan dinyatakan telah terimplementasi di STAI DR. KH. EZ. Muttaqien Purwakarta dengan baik dengan persentase jawaban 40\%, 29\% menyatakan sangat baik dan $27 \%$ menyatakan cukup baik.

d. Sistem Informasi Akademik yang mudah diakses dimanapun dan kapanpun dinyatakan telah terimplementasi di STAI DR. KH. EZ. Muttaqien Purwakarta dengan sangat baik dengan persentase jawaban $41 \%$ dan $36 \%$ menyatakan baik.

e. Kerahasiaan data Sistem Informasi Akademik yang terjamin aman dan tidak mudah di hack dinyatakan telah terimplementasi di STAI DR. KH. EZ. Muttaqien Purwakarta dengan sangat baik dengan persentase jawaban $42 \%$, $31 \%$ menyatakan baik dan $21 \%$ menyatakan cukup baik.

f. Penyampaian informasi tepat waktu dinyatakan telah terimplementasi di STAI DR. KH. EZ. Muttaqien Purwakarta dengan baik dengan persentase jawaban $38 \%, 26 \%$ menyatakan cukup baik dan $24 \%$ menyatakan sangat baik.

g. Informasi data disajikan sesuai kebutuhan dan sesuai dengan kegiatan telah terimplementasi di STAI DR. KH. EZ. Muttaqien Purwakarta dengan baik dengan persentase jawaban 45\%, 29\% menyatakan sangat baik dan $22 \%$ menyatakan cukup baik.

h. Ketersediaan Informasi KRS dan KHS online yang sudah lengkap telah terimplementasi di STAI DR. KH. EZ. Muttaqien Purwakarta dengan baik dengan persentase jawaban 35\%, 30\% menyatakan cukup baik dan $27 \%$ menyatakan sangat baik.

i. Kemudahan dalam Pengambilan KRS dan KHS secara Online kegiatan telah terimplementasi di STAI DR. KH. EZ. Muttaqien Purwakarta dengan cukup baik dengan persentase jawaban $36 \%$, $28 \%$ menyatakan baik dan $15 \%$ menyatakan sangat baik.

j. Proses informasi Nilai di SIAKAD mengalami kemudahan telah terimplementasi di STAI DR. KH. EZ. Muttaqien Purwakarta dengan cukup baik dengan persentase jawaban $40 \%$, $24 \%$ menyatakan baik dan $15 \%$ menyatakan sangat baik.

Hasil survey diatas menunjukkan jumlah rata-rata sebagai berikut:

Tabel 2.

Persentase Rata-Rata Persepsi

Mahasiswa terhadap Implementasi

Siakad

\begin{tabular}{|c|l|c|}
\hline No & Keterangan & Persentase \\
\hline 1 & Sangat Baik & $28,45 \%$ \\
\hline 2 & Baik & $36,33 \%$ \\
\hline 3 & Cukup Baik & $26,13 \%$ \\
\hline 4 & Kurang Baik & $6,94 \%$ \\
\hline 5 & Tidak Baik & $2.13 \%$ \\
\hline & Jumlah & $100 \%$ \\
\hline
\end{tabular}

menggambarkan bahwa Implementasi Sistem Informasi Akademik di STAI DR. KH. EZ. Muttaqien Purwakarta, disetujui telah terwujud. Angkanya cukup tinggi yaitu $28,45 \%$ menyatakan sangat baik dan $36,33 \%$ menyatakan baik. Hal ini menunjukkan bahwa implementasi Sistem Informasi Akademik di STAI DR. KH. EZ. Muttaqien Purwakarta dipersepsikan telah terwujud dengan baik.

\section{Implementasi Akuntabilitas Akademik di STAI DR. KH. EZ. Muttaqien Purwakarta}


Selanjutnya untuk melihat bagaimana gambaran implementasi akuntabilitas Akademik STAI DR. KH. EZ. Muttaqien Purwakarta peneliti menyebar angket staff pengelola akun SIAKAD dan Pimpinan di STAI DR. KH. EZ. Muttaqien Purwakarta dari sejumlah data yang terisi sejumlah $57,14 \%$ pengelola SIAKAD dan $38,88 \%$ Piminan STAI berpartisipasi dalam memberikan sejumlah data yang berkaitan dengan akuntabilitas akademik di STAI.

Adapun pernyataan penelitian yang menggambarkan Akuntabilitas Akademik melalui sudut pandang Staff Pengelola SIAKAD STAI DR. KH. EZ. Muttaqien Purwakarta adalah sebagai berikut:

a. Pelayanan akademik memiliki dan menjalankan standar oerasional prosedur (SOP);

b. Memiliki sumber daya manusia yang memadai dan kompeten dalam pelayanan akademik;

c. Pelayanan akademik mampu menunjang meningkatnya motivasi dan prestasi mahasiswa dalam kegiatan akademik;

d. Fakultas telah menggunakan sistem informasi untuk kepentingan layanan akademik mahasiswa;

e. Menjadi support system dalam perencanaan strategis fakultas dalam mencapai tujuannya;

f. Proses perencanaan akademik dan layanan akademik berjalan efektif;

g. Sistem informasi manajemen akademik mendukung secara maksimal proses pengambilan keputusan;

h. Produktivitas dalam aplikasi pengembangan dan pemeliharaan sistem memadai;

i. Sistem Informasi manajemen akademik efektif mendukung kepentingan akreditasi program studi di lingkungan fakultas;

j. Sistem informasi manajemen akademik menjadi pengendali kegiatan akademik.

Berikut hasil survei Akuntabilitas Akademik yang diberikan oleh responden dengan berdasarkan pada kesepuluh pernyataan penelitian yang kemudian di jawab dengan skala linkert sangat baik, baik, cukup baik, kurang baik dan tidak baik.

\section{Gambar 2.}

Hasil Survey Akuntabilitas Akademik

\section{Akuntabilitas Akademik}

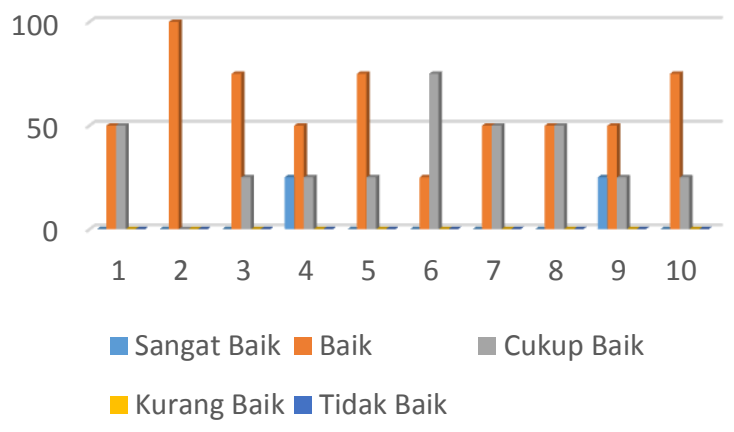

Berikut ini adalah deskripsi dan hasil temuan lapangan menunjukkan data sebagai berikut:

a. Pelayanan akademik memiliki dan menjalankan standar operasional prosedur (SOP) telah terimplementasi di STAI DR. KH. EZ. Muttaqien Purwakarta dengan dengan persentase jawaban $50 \%$ menyatakan baik dan $50 \%$ menyatakan cukup baik;

b. Memiliki kompetensi dalam pengelolaan Sistem Informasi Akademik telah terimplementasi di STAI DR. KH. EZ. Muttaqien Purwakarta dengan baik dengan persentase jawaban $100 \%$;

c. Pelayanan akademik mampu menunjang meningkatnya motivasi dan prestasi mahasiswa dalam kegiatan akademik telah terimplementasi di STAI DR. KH. EZ. Muttaqien Purwakarta dengan persentase jawaban $75 \%$ menyatakan baik dan $25 \%$ cukup baik;

d. STAI telah menggunakan sistem informasi untuk kepentingan layanan akademik mahasiswa telah terimplementasi di STAI DR. KH. EZ. 
Muttaqien Purwakarta dengan persentase jawaban 50\% menyatakan baik, $25 \%$ menyatakan sangat baik dan $25 \%$ menyatakan cukup baik;

e. Sistem informasi menjadi support system dalam perencanaan strategis Prodi dalam mencapai tujuannya telah terimplementasi di STAI DR. KH. EZ. Muttaqien Purwakarta dengan persentase jawaban $75 \%$ menyatakan baik, dan $25 \%$ menyatakan cukup baik;

f. Proses perencanaan akademik dan layanan akademik yang berjalan efektif telah terimplementasi di STAI DR. KH. EZ. Muttaqien Purwakarta dengan persentase jawaban $75 \%$ menyatakan cukup baik, dan $25 \%$ menyatakan baik;

g. Sistem informasi akademik mendukung yang secara maksimal proses pengambilan keputusan telah terimplementasi di STAI DR. KH. EZ. Muttaqien Purwakarta dengan persentase jawaban $50 \%$ menyatakan cukup baik dan $50 \%$ menyatakan baik;

h. Produktivitas dalam aplikasi pengembangan dan pemeliharaan sistem memadai telah terimplementasi di STAI DR. KH. EZ. Muttaqien Purwakarta dengan persentase jawaban $50 \%$ menyatakan cukup baik, dan $50 \%$ menyatakan baik.

i. Sistem Informasi akademik efektif mendukung kepentingan akreditasi program studi di lingkungan STAI telah terimplementasi di STAI DR. KH. EZ. Muttaqien Purwakarta dengan persentase jawaban $50 \%$ menyatakan baik, $25 \%$ menyatakan sangat baik dan $25 \%$ menyatakan cukup baik.

j. Sistem informasi akademik menjadi pengendali kegiatan akademik telah terimplementasi di STAI DR. KH. EZ. Muttaqien Purwakarta dengan persentase jawaban $75 \%$ menyatakan baik dan $25 \%$ menyatakan cukup baik.
Hasil survey diatas menunjukkan jumlah rata-rata sebagai berikut:

Tabel 3.

Persentase Akuntabilitas Akademik

\begin{tabular}{|c|l|c|}
\hline No & Keterangan & Persentase \\
\hline 1 & Sangat Baik & $5 \%$ \\
\hline 2 & Baik & $60 \%$ \\
\hline 3 & Cukup Baik & $35 \%$ \\
\hline 4 & Kurang Baik & $0 \%$ \\
\hline 5 & Tidak Baik & $0 \%$ \\
\hline & Jumlah & $100 \%$ \\
\hline
\end{tabular}

Adapun pernyataan penelitian yang menggambarkan Akuntabilitas Akademik melui sudut pandang Pimpinan STAI DR. KH. EZ. Muttaqien Purwakarta adalah sebagai berikut:

a. Aksesibilitas data tersaji secara tepat waktu dan akurat bagi pengguna seluruh stakeholder

b. Efektifitas dan efisiensi dalam melaksanakan prosedur akademik bagi pengguna dan seluruh stakeholder

c. Kemudahan akses input dan output data yang berkaitan dengan pelayanan akademik

d. Adanya pengembangan dan pemeliharaan sistem agar memadai

e. Kemudahan menyampaikan masalah yang yang terjadi dalam sistem informasi akademik

f. Pelayanan akademik tatap muka memuaskan

g. Agenda akademik (KRS, dll) berjalan dengan disiplin sesuai waktu yang ditetapkan

h. Menyediakan informasi yang dipergunakan dalam perencanaan, pengendalian, pengevaluasian, dan perbaikan berkelanjutan

i. Menyediakan informasi untuk pengambilan keputusan akademik

j. Mendukung kepentingan akreditasi program studi di lingkungan STAI

Berikut hasil survei Akuntabilitas Akademik yang diberikan oleh responden dengan berdasarkan pada kesepuluh pernyataan penelitian yang kemudian di 
jawab dengan skala linkert sangat baik, baik, cukup baik, kurang baik dan tidak baik.

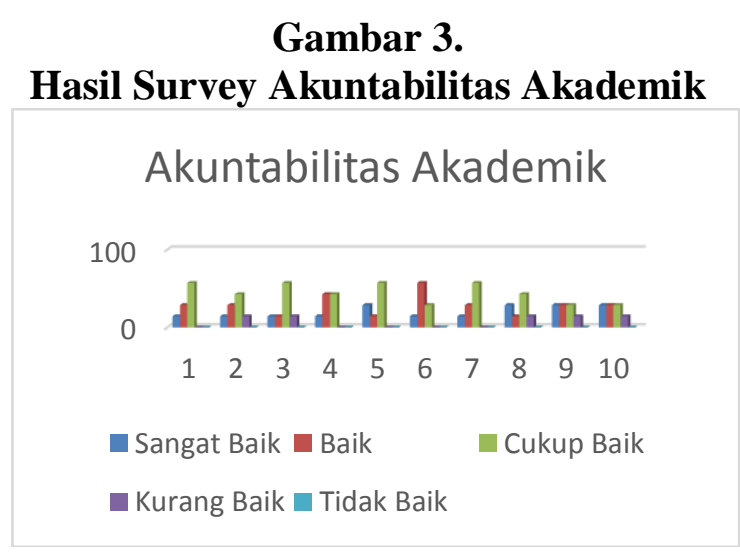

Berikut ini adalah deskripsi dan hasil temuan lapangan menunjukkan data sebagai berikut:

a. Aksesibilitas data tersaji secara tepat waktu dan akurat bagi pengguna seluruh stakeholder telah terimplementasi di STAI DR. KH. EZ. Muttaqien Purwakarta dengan persentase jawaban $14 \%$ menyatakan sangat baik dan $29 \%$ menyatakan baik.

b. Efektifitas dan efisiensi dalam melaksanakan prosedur akademik bagi pengguna dan seluruh stakeholder telah terimplementasi di STAI DR. KH. EZ. Muttaqien Purwakarta dengan persentase jawaban $14 \%$ menyatakan sangat baik dan $29 \%$ menyatakan baik.

c. Kemudahan akses input dan output data yang berkaitan dengan pelayanan akademik telah terimplementasi di STAI DR. KH. EZ. Muttaqien Purwakarta dengan persentase jawaban $14 \%$ menyatakan sangat baik dan $14 \%$ menyatakan baik.

d. Adanya pengembangan dan pemeliharaan sistem agar memadai telah terimplementasi di STAI DR. KH. EZ. Muttaqien Purwakarta dengan persentase jawaban $14 \%$ menyatakan sangat baik dan $43 \%$ menyatakan baik. e. Kemudahan menyampaikan masalah yang yang terjadi dalam sistem informasi akademik telah terimplementasi di STAI DR. KH. EZ. Muttaqien Purwakarta dengan persentase jawaban 29\% menyatakan sangat baik dan $14 \%$ menyatakan baik.

f. Pelayanan akademik tatap muka memuaskan telah terimplementasi di STAI DR. KH. EZ. Muttaqien Purwakarta dengan persentase jawaban $14 \%$ menyatakan sangat baik dan $57 \%$ menyatakan baik.

g. Agenda akademik (KRS, dll) berjalan dengan disiplin sesuai waktu yang ditetapkan telah terimplementasi di STAI DR. KH. EZ. Muttaqien Purwakarta dengan persentase jawaban $14 \%$ menyatakan sangat baik dan $29 \%$ menyatakan baik.

h. Menyediakan informasi yang dipergunakan dalam perencanaan, pengendalian, pengevaluasian, dan perbaikan berkelanjutan telah terimplementasi di STAI DR. KH. EZ. Muttaqien Purwakarta dengan persentase jawaban $29 \%$ menyatakan sangat baik dan $14 \%$ menyatakan baik.

i. Menyediakan informasi untuk pengambilan keputusan akademik telah terimplementasi di STAI DR. KH. EZ. Muttaqien Purwakarta dengan persentase jawaban 29\% menyatakan sangat baik dan $29 \%$ menyatakan baik.

j. Mendukung kepentingan akreditasi program studi di lingkungan STAI telah terimplementasi di STAI DR. KH. EZ. Muttaqien Purwakarta dengan persentase jawaban $29 \%$ menyatakan sangat baik dan $29 \%$ menyatakan baik.

Hasil survey diatas menunjukkan jumlah rata-rata sebagai berikut:

Tabel 4.

Persentase Akuntabilitas Akademik

\begin{tabular}{|l|l|l}
\hline No & Keterangan & Persentase
\end{tabular}




\begin{tabular}{|c|l|c|}
\hline 1 & Sangat Baik & $20 \%$ \\
\hline 2 & Baik & $28,57 \%$ \\
\hline 3 & Cukup Baik & $44,28 \%$ \\
\hline 4 & Kurang Baik & $7,14 \%$ \\
\hline 5 & Tidak Baik & $0 \%$ \\
\hline & Jumlah & $100 \%$ \\
\hline
\end{tabular}

Apabila di gabung angka rata-rata antara staff pengelola SIAKAD dengan piminan STAI DR. KH. EZ. Muttaqien Purwakarta, maka diperoleh angka rata-rata sebagai berikut:

Tabel 5.

Persentase Akuntabilitas Akademik

\begin{tabular}{|c|l|c|}
\hline No & \multicolumn{1}{|c|}{ Keterangan } & Persentase \\
\hline 1 & Sangat Baik & $13 \%$ \\
\hline 2 & Baik & $44 \%$ \\
\hline 3 & Cukup Baik & $40 \%$ \\
\hline 4 & Kurang Baik & $4 \%$ \\
\hline 5 & Tidak Baik & $0 \%$ \\
\hline & Jumlah & $100 \%$ \\
\hline
\end{tabular}

Berdasarkan data diatas, menggambarkan bahwa Akuntabilitas Akademik di STAI DR. KH. EZ. Muttaqien Purwakarta, disetujui telah terwujud. Angkanya cukup tinggi yaitu $13 \%$ menyatakan sangat baik dan $44 \%$ menyatakan baik. Hal ini menunjukkan bahwa implementasi Sistem Informasi Akademik di STAI Dr. KHEZ. Muttaqien dipersepsikan telah terwujud dengan baik.

\section{Implementasi Sistem Informasi} Akademik terhadap Akuntabilitas Akademik di STAI DR. KH. EZ. Muttaqien Purwakarta

Berdasarkan hasil penelitain di atas, menggambarkan bahwa implementasi SIAKAD disetujui telah terwujud di kampus STAI DR. KH. EZ. Muttaqien Purwakarta. Angkanya jumlah rata-rata menunjukkan $64,78 \%$ menyatakan baik dan sangat baik. Demikian juga dengan akuntabilitas akademik di STAI DR. KH. EZ. Muttaqien Purwakarta dipersepsikan telah terwujud dengan angka jumlah persentase $57 \%$ menyatakan baik dan sangat baik. Hal ini menunjukkan bahwa implementasi sistem informasi manajemen akademik berdampak terhadap akuntabilitas akademik di STAI DR. KH. EZ. Muttaqien Purwakarta.
Sebagaimana diketahui, sistem informasi akademik adalah sistem perencanaan bagian dari pengendalian internal suatu institusi pendidikan yang meliputi pemanfaatan manusia, dokumen, teknologi, dan prosedur standar untuk memecahkan masalah akademik seperti rencana studi, hasil studi, transkrip nilai, grafik nilai, kartu hak ujian, daftar hadir mahasiswa, dll. Sistem informasi akademik digunakan untuk menganalisis sistem informasi lain yang diterapkan pada institusi pendidikan. Secara akademis, istilah ini umumnya digunakan untuk merujuk pada kelompok metode manajemen informasi yang bertalian dengan otomasi atau dukungan terhadap pengambilan keputusan manusia, misalnya sistem pendukung keputusan, sistem pakar, dan sistem informasi pimpinan.

Siakad STAI DR. KH. EZ. Muttaqien Purwakarta adalah sebuah sistem yang cukup kompleks. Sistem ini dapat berjalan dengan baik apabila semua proses didukung dengan teknologi yang tinggi, sumber daya yang berkualitas, dan yang paling penting komitmen institusi. Siakad berguna untuk mendukung fungsi manajemen, akademik, dan pengambilan keputusan dalam sebuah institusi pendidikan tinggi. Sistem Informasi Akademik bertujuan menghasilkan informasi yang berguna untuk perusahaan. Kegiatan ini mendukung proses akademik pendidikan tinggi dan perlu diperhatikan untuk kelangsungan institusi tersebut. Oleh karena itu, komitmen institusi pendidikan tinggi untuk menjalankan Siakad haruslah sangat tinggi agar proses yang terjadi dapat memberikan manfaat bagi institusi pendidikan tinggi yang dimaksud. (Julian: 2013)

Supaya informasi yang dihasilkan oleh sistem informasi dapat berguna bagi pimpinan, maka analis sistem harus mengetahui kebutuhan-kebutuhan informasi yang dibutuhkannya, yaitu dengan mengetahui kegiatan-kegiatan untuk masingmasing tingkat (level) manajemen dan tipe keputusan yang diambilnya. Berdasarkan pada pengertian-pengertian di atas, maka terlihat bahwa tujuan dibentuknya Siakad adalah supaya institusi pendidikan memiliki informasi yang bermanfaat dalam pembuatan keputusan manajemen, baik yang menyangkut 
keputusan-keputusan rutin maupun keputusan-keputusan yang strategis.

Akuntabilitas adalah sebuah konsep etika yang dekat dengan administrasi publik pemerintahan yang mempunyai beberapa arti antara lain, hal ini sering digunakan secara sinonim dengan konsep-konsep seperti yang dapat dipertanggungjawabkan (responsibility), kemampuan memberikan jawaban (answerability), yang dapat dipersalahkan (blameworthiness) dan yang mempunyai ketidakbebasan (liability) termasuk istilah lain yang mempunyai keterkaitan dengan harapan dapat menerangkan salah satu aspek dari administrasi publik atau pemerintahan, hal ini sebenarnya telah menjadi pusat-pusat diskusi yang terkait dengan tingkat probabilitas di sektor publik, perusahaan nirlaba, yayasan dan perusahaan-perusahaan.

Dalam kajian Ilmu Akuntansi, akuntabilitas diartikan sebagai pertanggungjelasan. Suatu organisasi dikatakan akuntabel jika memiliki kemampuan untuk menjelaskan kondisi yang dialami termasuk didalamnya keputusan yang diambil dan berbagai aktivitas yang dilakukan. Istilah akuntabilitas dalam bidang ilmu akuntansi dipisahkan dengan istilah responsibilitas atau diartikan sebagai pertanggungjawaban.

Dalam peran kepemimpinan, akuntabilitas dapat merupakan pengetahuan dan adanya pertanggungjawaban tehadap tiap tindakan, produk, keputusan dan kebijakan termasuk pula di dalamnya administrasi publik pemerintahan, dan pelaksanaan dalam lingkup peran atau posisi kerja yang mencakup di dalam mempunyai suatu kewajiban untuk melaporkan, menjelaskan dan dapat dipertanyakan bagi tiap-tiap konsekuensi yang sudah dihasilkan.

Akuntabilitas merupakan istilah yang terkait dengan tata kelola pemerintahan sebenarnya agak terlalu luas untuk dapat didefinisikan. Akan tetapi hal ini sering dapat digambarkan sebagai hubungan antara yang menyangkut saat sekarang ataupun masa depan, antar individu, kelompok sebagai sebuah pertanggungjawaban kepentingan merupakan sebuah kewajiban untuk memberitahukan, menjelaskan terhadap tiap- tiap tindakan dan keputusannya agar dapat disetujui maupun ditolak atau dapat diberikan hukuman bilamana diketemukan adanya penyalahgunaan kewenangan.

Aturan dan norma internal serta beberapa komisi independen adalah mekanisme untuk menampung birokrasi dalam tanggung jawab administrasi pemerintah. Dalam kementerian atau pelayanan, pertama, perilaku dibatasi oleh aturan dan peraturan; kedua, pegawai negeri dalam hierarki bawahan bertanggung jawab kepada atasan. Dengan diikuti adanya unit pengawas independen guna memeriksa dan mempertanggung jawabkan, legitimasi komisi ini dibangun di atas kemerdekaan mereka agar dapat terhindar dari konflik kepentingan apapun. Selain dari pemeriksaan internal, terdapat pula beberapa unit pengawas yang bertugas untuk menerima keluhan dari masyarakat sebagai akuntabilitas kepada warga negara.

Dengan memperhatikan hasil penelitian yang sudah dilakukan dan konsep yang seharusnya, ditemukan beberapa kesimpulan penelitian dari keberadaan Siakad di STAI DR. KH. EZ. Muttaqien Purwakarta, meski belum sempurna, adalah sebagai berikut:

a. Aksesibilitas data tersaji secara tepat waktu dan akurat bagi para pemakai, tanpa mengharuskan adanya perantara sistem informasi;

b. Tersedianya kualitas dan keterampilan dalam memanfaatkan sistem informasi secara kritis secara merata;

c. Proses perencanaan yang efektif;

d. Mengidentifikasi kebutuhan-kebutuhan akan keterampilan pendukung sistem informasi;

e. Menetapkan investasi yang akan diarahkan pada sistem informasi;

f. Mengantisipasi dan memahami konsekuensi-konsekuensi ekonomis dari sistem informasi dan teknologi baru;

g. Produktivitas dalam aplikasi pengembangan dan pemeliharaan sistem memadai; 
h. Program Studi bisa menggunakan sistem informasi untuk kepentingan layanan akademik mahasiswa;

i. Sistem Informasi Akademik dapat mendukung secara maksimal proses pengambilan keputusan;

j. Sistem Informasi Akademik menjadi pengendali kegiatan akademik;

k. Sistem Informasi Akademik menjadi support system dalam perencanaan strategis.

1. Sistem Informasi Akademik efektif mendukung kepentingan akreditasi program studi di lingkungan STAI.

Sebagaimana telah dijelaskan sebelumnya, bahwa sistem informasi termasuk sistem informasi akademik diangap mampu meraih tujuan institusi, yaitu:

a. Menyediakan informasi yang dipergunakan dalam bidang akademik dan tujuan lain yang diinginkan pimpinan;

b. Menyediakan informasi yang dipergunakan dalam perencanaan, pengendalian, pengevaluasian, dan perbaikan berkelanjutan;

c. Menyediakan informasi untuk pengambilan keputusan.

Oleh karena itu, agar tujuan tersebut dapat tercapai dengan baik, perlu pendalaman terkait dengan beberapa variabel penting sebagai berikut:

a. Pendalaman terkait dengan tujuan Siakad STAI DR. KH. EZ. Muttaqien Purwakarta;

b. Pendalaman terkait dengan instrumen akreditasi program studi;

c. Deskripsi orientasi kurikulum program studi mulai aspek filosofis strategis hingga hal yang bersifat administratif akademik;

d. Deskripsi proses penjaminan mutu program studi dan perangkatperangkatnya;

e. Deskripsi kajian ilmu di STAI DR. KH. EZ. Muttaqien Purwakarta dalam perspektif sistem informasi manajemen untuk menunjang akreditasi program studi.

\section{KESIMPULAN}

\begin{tabular}{lccr}
\multicolumn{2}{c}{ Berdasarkan } & hasil & penelitain \\
sebagaimana & yang & sudah & disebutkan \\
sebelumnya, & menggambarkan & bahwa
\end{tabular} implementasi Siakad di STAI DR. KH. EZ. Muttaqien Purwakarta dinyatakan baik. Jumlah rata-rata menunjukkan $64,78 \%$ menyatakan baik dan sangat baik. Demikian juga dengan akuntabilitas akademik di STAI DR. KH. EZ. Muttaqien Purwakarta dipersepsikan telah terwujud dengan angka jumlah persentase $57 \%$ menyatakan baik dan sangat baik. Hal ini menunjukkan bahwa implementasi sistem informasi manajemen akademik berdampak terhadap akuntabilitas akademik di STAI DR. KH. EZ. Muttaqien Purwakarta.

Dengan memperhatikan hasil penelitian yang sudah dilakukan dan konsep yang seharusnya, ditemukan beberapa kesimpulan penelitian dari keberadaan Siakad pada di STAI DR. KH. EZ. Muttaqien Purwakarta (meski belum sempurna) adalah sebagai berikut: 1) Sistem pengambilan mata kuliah yang di sediakan oleh Sistem Informasi Akademik terorganisir; 2) Informasi yang diberikan oleh Sistem Informasi Akademik jelas dan cepat; 3) Pengoperasian Sistem Informasi Akademik mudah dan dapat mempermudah kegiatan kemahasiswaan dan perkuliahan; 4) Sistem Informasi Akademik mudah diakses dimanapun dan kapanpun; 5) Kerahasiaan data Sistem Informasi Akademik terjamin aman dan tidak mudah di hack; 6) Penyampaian informasi tepat waktu; 7) Informasi data disajikan sesuai kebutuhan dan sesuai dengan kegiatan; 8) Ketersediaan Informasi KRS dan KHS online sudah lengkap; 9) Mengalami Kemudahan dalam Pengambilan KRS dan KHS secara Online; 10) Proses informasi Nilai di SIAKAD mengalami kemudahan; 11) Produktivitas dalam aplikasi pengembangan dan pemeliharaan sistem memadai; 12) Prodi bisa menggunakan sistem informasi untuk kepentingan layanan akademik mahasiswa; 13) Sistem Informasi Akademik dapat mendukung secara maksimal proses pengambilan keputusan; 14) Sistem Informasi 
Akademik menjadi pengendali kegiatan akademik; 15) Sistem Informasi Akademik menjadi support system dalam perencanaan strategis.Tujuan perencanaan strategis adalah untuk mengembangkan strategi dimana prodi dan institusi akan mampu mencapai tujuannya. Sistem Informasi Akademik efektif mendukung kepentingan akreditasi program studi di lingkungan Sekolah Tinggi.

\section{Daftar Pustaka}

Agoeng Koerniawan dan Arief Darmawan, (2016). Implementasi Program Sistem Informasi Akademik Siakad Di STKIP PGRI Bangkalan, diakses pada tanggal 28/12/2020 dari garuda.ristekdikti.go.id.

Agung Dananjaya Putra dan Gede Juliarsa, (2016). Pengaruh Task-Technology Fit Terhadap Kinerja Individual Pada Maya Sanur Resort \& Spa, E-Jurnal Akuntansi Universitas Udayana Vol.16.2.

Akadun, (2009). Teknologi Informasi Administrasi, Bandung: Alpabeta.

Etin Indrayani, (2011). Pengelolaan Sistem Informasi Akademik Perguruan Tinggi Berbasis Teknologi Informasi Dan Komunikasi (TIK), Jurnal Penelitian Pendidikan Vol. 12 No. 1 April 2011. ISSN 1412-565X.

Herson Anwar, (2016). Penerapan Sistem Informasi Akademik (Siakad) Dalam Meningkatkan Layanan Akademik Di Prodi Manajemen Pendidikan Islam Fakultas Ilmu Tarbiyah Dan Keguruan Iain Sultan Amai Gorontalo, TADBIR : Jurnal Manajemen Pendidikan Islam Volume 4, Nomor 1 : Februari 2016.

Jogiyanto, (2003). Sistem TeknologiInformasi, Yogyakarta: Penerbit Andi Offset.

Jogiyanto, (1997). Model Kesuksesan Sistem Teknologi Informasi. Yogyakarta: Penerbit Andi Offset.

Kristanto Herianto, (1994). Konsep dan Perancangan Database. Yogyakarta: Penerbit Andi Offset.

Lexy Moloeng, (1993). Metodologi Penelitian Kualitatif, Bandung: Remaja Rosdakarya.
Moekijat Prasojo, (2011) Pengantar Sistem Informasi, Bandung: Remaja Rosdakarya.

Pujihastuti, I. (2010). Prinsip penulisan kuesioner penelitian. CEFARS: Jurnal Agribisnis dan Pengembangan Wilayah, 2(1), 43-56.

Roby Novianto, (2020), Analysis Of Success Factor Sistem Informasi Akademik (Siakad) Use The Delone And Mclean Model (Case Study STIE Muhammadiyah Pringsewu Lampung). Jurnal TAM (Technology Acceptance Model) Volume 11, Nomor 1, Juli 2020.

Sony Yuwono, dkk, (2002). Petunjuk Praktis Penelitian Balanced Scorecard: Menuju Organisasi yang Berfokus pada Strategi, Jakarta: Gramedia Pustaka Utama.

Sri Maharsi, Pengaruh Perkembangan Teknologi Informasi Terhadap Bidang Akuntansi Manajemen. Jurnal Akuntansi Keuangan Vol. 2, No. 2.

Sugiyono, (2009). Memahami Penelitian Kualitatif, Bandung: Alfabeta.

Suharsimi Arikunto, (2002). Prosedur Penelitian, Suatu Pendekatan Praktek, Jakarta: Bina Aksara.

Tata Sutabri, (2010). Analisa Sistem Informasi. Yogyakarta: Penerbit Andi Offset.

Widodo, U. (2021). Uji Signifikansi Pengaruh Kreativitas Belajar pada Keterampilan Membaca Siswa. Kajian Bahasa, Sastra Dan Pengajaran, 5(2), 95-106. https://doi.org/https://doi.org/10.31539/k ibasp.v5i1.2970 